\title{
HIP1 Gene
}

National Cancer Institute

\section{Source}

National Cancer Institute. HIP1 Gene. NCI Thesaurus. Code C97537.

This gene plays a role in both vesicle coat formation and endocytosis. 